\title{
Cultural Heritage and Tourism Prospects: A study on the Mela Festivals of the Tiwas of Middle Assam
}

\author{
Trailokya Borkakati \\ Asst. Professor, Dept of English \\ Diphu Govt. College \\ DOI: 10.29322/IJSRP.10.05.2020.p10145 \\ http://dx.doi.org/10.29322/IJSRP.10.05.2020.p10145
}

\begin{abstract}
The various calendric and seasonal festivals celebrated by the Tiwas Middle Assam are a shared sequence of experience, civic as well as religious and emotional interaction. Games, Dance and Feast that reveal public expression of community satisfaction and good will, ingrain both historical as well as geographical tradition. The Junbeel Mela, Gossain Ulliuwa Mela Festival, Melas of Dantialia Rajya (Tiwa Kingdom) and melas of Sato Rajya, Pacho Rajya and other kingdoms bear the resemblances regarding the process of observation of their melas. The Junbeel Mela is the significant seasonal festival observed by the Tiwas of Morigaon and West Karbi Anglong District. The noteworthy significant of the festival is the 'Barter System' which takes place in between the hill and plain people. The Gosain Ulliuwa Mela festival plays a great role in the folk culture of Middle Assam (basically Morigaon and Nagaon district) and reflects a distinct picture of Tiwa folk performing art ensuing the Neo-Vaishnavite influence in its celebration.

Traditionally visitors, tourists and research scholars come to the Junbeel Mela from different parts of the state of Assam and other parts of the state of Assam and other parts of the country. But the other festivals are lagging behind. Obviously there are good prospects for tourism in this sector of historical and cultural celebrations. This paper is an attempt to look into different constraints and prospects of tourism development in the study area with the help of modern technology and media.
\end{abstract}

Keywords: Tiwas, Junbeel, Mela, Pacho Rajya.

\section{Introduction}

The term 'Mela' means fairs and festivals and in plain meaning festivals indicate a season of social mirth when series of performances of music, plays feast or the like honorific celebrations of historical events are enacted by a community. British and continental folklorists found these celebrations as recurring moments of special significance and are called festivals.

The folk festivals celebrated by the people of middle Assam are both of seasonal and calenderic festivals. The common festivals of the Assamese Hindus are also celebrated by the Hindu peoples of the district. There are some specific festivals of the Tiwasin the district. The GosainUlliowaMela, Bihu festivals with slight variation, JunbeelMela and Barat Festival are some specific festivals. The Sagra Misawa and Wansuwa (festival of pounding rice flour) festivals are celebrated only by the Hill Tiwas of KarbiAnglong District at present.

The Tiwas established several princely states in Nagaon known as kingdom of Pachoraja and Satoraja. The ancient kingdoms cover some areas of present Jayantia hills (Meghalaya) and some area of KarbiAnglong and Nagaon district. The Lalung 
presently inhabited mainly in the villages of Morigaon District are- Silchang, Dahali, Makaria, Nelli, Palashguri, Beltola, Baolagug, Sonaikuchi, Kamarkuchi, Gaonliakuchi, Markangkuchi, Gova, Khala, Pachim-nagaon, Barapujia, Charaibahi, Baghara, Manipur, Nakhola, Baha, Jagi, Bhakatgaon, Mayong, Chabukdhara etc.

The other Assamese caste Hindu communities of Middle Assam are the Brahmins, Kalita, Keot, Nath-Yogi, Koch, Chutia, Kaivartta, Hira and a few Ahom people. All the communities celebrate the common Assamese seasonal festivals. Some special festivals are - Bihu Festival, Durga Puja, Lakshmi Puja Festivals, religious festivals like RasaMahotsava, the Bhaonafestivalby performing many Ankiya dramas and Neo-vaishnavite Festivals in different places of the area.

This study looks at the Mela festivals - The JunbeelMela, TiwaGosaiUliuwaMela, Melasof Sato Rajya, PachoRajya and other kingdoms of Tiwasand to study the prospects of tourism development.

\section{Objectives}

1. To assess the cultural heritage of the concerning Mela Festivals of the Tiwas.

2. To study the linkage of Mela festivals and tourism development in the study region.

3. To highlight the prospects of tourism in the region.

\section{Methodology}

The research paper is the form of a brief study of the Mela festivals which will maintain bright prospect of cultural and economic development in terms of tourism industry. The present study is based on various published sources like books, journals, souvenirs and close observation of the Mela festivals.

\section{The Mela festivals of the Tiwas of Middle Assam}

1. JunbeelMela

2. TiwaGosaiUliuwaMela.

1. Junbeel Mela

It is the most significant seasonal festival observed by the Tiwas. Junbeel is a famous beel (wet land) which is situated about $5 \mathrm{kms}$ away from Jagiroad revenue Town. In the month of January during the Magh Bihu this fair festival helds. JunbeelMela is being carried traditional significance among the Tiwas even to these days.

A nice legend is behind this Junbeel. Once a Tiwa King was traveling besides the beel and delighted by looking the image of the moon on the water of the beel. Then he said, "Hebe SonainePilHango" 
means this is the beel of the moon only. In Tiwa language, Sonai means moon. As time passed the beel is regarded as Sonaibil-Jonaibeel-Junbeel. So the fair that is held just beside the beel is known as JunbeelMela. This is not only a fair but a field of unity and assimilation of hill and the plain people.

The celebration of JunbeelMela festivals was first introduced by the Gova king "Rai Singha". Gova is the greatest kingdom of Tiwa, $15 \mathrm{kms}$ away from Jagiroad. At present also the Gova king inaugurates this mela in traditional formalities on the very first day. Every year after worshiping "Lord Mahadeo" in Deosal, people use to enjoy and celebrate it. This Mela starts on Wednesday and ends on Saturday. Fishing in group on the occasion of JunbeelMela is a trend to the onlookers. Groups of people go to the beel and construct artificial barrier with mud. Then the entire group of people suddenly jump over barricaded water and the fish with the help of fishing tools like Poloand Juluki etc.

In ancient time Gova king collected tax from his subjects and subordinate kings. The noteworthy significant of this festival is the 'Barter System'. The system takes place in between the hilly and plain people. They exchange their commodities. Hill people are from Tiwa, Karbi andJayantia. They carry chilli, potato, arum, turmeric, ginger, bamboo salad exchange it with dry fish, mastered seed, kerosene, endi cloth, cakes and betel nuts that the plain people bring with them.

\section{TiwaGosaiUliuwaMela:}

The GosaiUliuwaMela festival is a remarkable festival of the middle Assam. At first, it was observed under the patronage of the Tiwa and koch kings. These Melas are arranged and observed on different dates at different places in Nagaon and Morigaon districts of Assam throughout the whole Bohag and Jestha (April-May) month. The whole month of Bohag and Jaitha (April-May) is season of special festival next to Bohag Bihu. The people of middle Assam, i.e. Nagaon and Morigaon are not legging behind in this case. They have the tradition of Mela which is known as 'Mela', 'Gosaiuliuwa' or 'Gosailia'

Initially these Melas were organized by the Tiwa Vassal Kings. The were the kings of

DantialiaRajya - Gobha, Nellie, Khola and Chahari.

Sato Rajya - Tetelia, Kumoi, Ghagua, Sukhanagog, Bhaghara, Tarani

and

Kacharigaon.

PachoRajya - Mikirgayan, Barapujia, Topakuchi, Khaigaria and Saragayan.

Other Kingdom - $\quad$ Mayang, Damal and Dandua are separate kingdoms not enlisted in the Sato Rajya and PachoRajya group. 
The above Melas were observed initially. But the descendants and scions established new colonies and they arranged annually the Mela festival imitating the old tradition. The scions of Topakuchi Kingdom are (1) Phulaguri (2) Borkola (3) Kachamari and Raidongia .The scions of Barapujia Kingdom are - (1) Kakamari (2) Chamuagaon (3) Kachamari-Boragaon. The scions of Mikirgaon Kingdom are - (1) Charaibahi (2) Dolongghat (3) Paghalialias Pahghali. and the scions of Chahari Kingdom are - (1) Bagariguri-Namgaon. (DeuriManeswar : $1994: 359-368)$

2.iMelas of DantialiaRajya :

(a) GobhaMela :

The most powerful and ancient most Kingdom among the DantialiaRajya is Gobha Kingdom. Gobha King deserved the credit of organizing four Melas of different characteristics on different times and at place of his Kingdom.

The first Mela is known as GobhaMela. It takes place at Gobha on the sixth day of 'Gobha Bihu'. It is notable here that Gobha Kingdom's 'Bohag Bihu' is celebrated after one week back of general 'Bohag Bihu' festival of Assam. The day is Friday as the 'Bihu' starts on Sunday.

(b) NakholaMela :

Nakhola is situated at Jagiroad town of Morigaon district. It is the head quarter of the Gobha King and his officers and can be regarded as the 'second capital' of Gobha. The King had chosen this place for convenient rule over his large Kingdom. As it is newly established mart (court yard), it is therefore ennamed as Na-Khola.

The Mela takes place at auspices of the King himself on the $7^{\text {th }}$ day of the 'Bohag Bihu' of Gobha. The day is Saturday and is just the following day of GobhaMela.

(c) KharbeelMela :

KharbeelMela is another Mela that has observing under the auspices ofGobha King. It is held on the eve of the Bohag Bihu of Gobha Kingdom on the bank ofa beel named 'Kharbeel'. It is completely a mart where Gobha King claimed his taxes from his subjects. This very Mela is held on Friday and Saturday. These days are regarded as 'Uruka' (the previous day of Bihu) as Bihu is always held on Sunday. Fishes are collected as tax from the people on Friday after fishing at the 'beel'. On Saturday a mart takes place where the goods are exchanged by barter. 
(d) Nellie Mela :

The Nellie Mela is held after one week back of the Bohag Bihu festival of Assam. The day is Saturday. On the preceding day, all the arrangement is done for Mela. Age old war weapons are bathed and sharpened to display on the Mela day. On the day, the idol of Lakshmi-Narayan with his seat is carried to Mela spot. The Kings, with music drums, dances proceed just after the seat. His officers accompany him. On the Mela, the King take his honourable seat and his subjects display drills with swords and shields of war-technique. At the evening the Lord's idol with his seat carried back to the 'Namghar' and re-installed there.

(e) Khola :

Khola (presently known as Silchang) King also has been celebrating a Mela from ancient time in the month of Bohag. The Mela is held for two days on Sunday and Monday after three back of their 'Bohag Bihu' celebration which take place on the first Wednesday of Bohag. It is notable here that for the Tiwas the Wednesday is a holy day and highly favourable for worship and other holy works.

(f) ChahariMela :

The King of Chahari was liable to perform four worships viz. - 'Kalikha Puja', 'Bauli Puja', 'Basundhari Puja' and 'Mahadeo Puja' on four different 'thans' before solemn his 'Bohag Bihu' and 'Mela'.

On the first day of Bihu (formely celebrated on the first Sunday of 'Bohag') the 'Basundhari Puja' is performed by the King. One day back 'Mahadeo Puja' is observed. One day back again the day of 'Rajarbhetiluwa' and the following day is Mela day.

2.ii. Melas of Sato Rajya, PachoRajya and other Kingdoms :

The Sato Rajya (seven Kingdoms), PachoRajya (five Kingdoms) and other petty Kingdoms of the Lalungs are situated on the northern bank of Kapilee river. All of the Kingdoms bear the same resemblance regarding the process of observation of their Melas. The process is as follows :

The officers of the King make their discussion and preparation of the Mela on its preceding day. The same day is the day 'adhibash' and fasting for the King. Toward night, the King worships his forefathers and the war weapons as well and makes sacrifices of fowls or eggs. On the day of Mela, 'NaamKirtan' is arranged either in the personal 'Namghar' of the King or in the general 'Namghar'. Different officers according to their post and position prepare the King for the Mela. Seat of Lord is bathed, swords are sharpened and shields are also cleaned carefully. Before going to the Mela field, the officers prepare the King. The officers entitled Bhandari dresses up the King; Sonamati adorns the King with ornaments and Dekaraja accompanies the King on 
the whole way to the Mela spot with an open umbrella over the head of the King. Then all proceed to the Mela spot with 'NaamKirtan' and with the music of war. The King follows the seat of the Lord. The sword and the shield holders keep their dances with the music of war. In the Mela spot too 'NaamKirtan' goes on in full swing and the expert people play with their swords and shield in front of the King. At evening, the Seat of Lord, swords and shields carried back to the King's house and re-instated there.

Now a days, in theseMela festivals, different rituals are seemed at different places. When the Vaishnavism entered to the Tiwa society, the Tiwas established 'Namghar' and 'Manikut'. The people established their Khatolas (Seat of Lord) and Simhasanas (archaic seat or Lord made of wood) in the Manikut of their Namghars. They move round the Manikut for seven times when the khatolas are brought out to that particular place on the day of the Mela in a procession. The practices and performances of the soldiers with sword and shields are not seen today in all the places. The people in the procession take part with GayanaBayana of Vaishnavite culture and singing the Naam-Kirtana using the instruments like Dova, Tal, Khol, KahandSangkha. The gathering in the Mela perform "NaamPrasang' in that afternoon and thereafter they return to the original place before night in the same day. Huge gathering of people of different caste and communities, shops and markets of stationary items, sweets and the music of drum and the socad of Naam-Prasangcreat an unprecedented atmosphere.

On the day of the Mela festival the villagers arrange different cultural programs and performance of AnkiaBhaonas in some places. In some places modern drama also staged by the local performers. Guests and relatives also come and enjoy the festival.

Today, the other communities of Assamese Hindus also observe thismela festival. At present, this GusaiUliuwaMela festival is not the festival of Tiwas, it has turned to a Vaishnavite festival of the Assamese Hindus of the district. Presently this GosaiUliuwaMela festival is celebrated in the month of Bohag and Jaith (April \& May) in more than sixty villages of the district. Some of these may be mentioned as - Dandua, Barapujia, Sapmari, Thanasarua, Naokata, Sidhabari, Kumuraguri, Tetelia, Barangabari, Kahibari, Sarubori, Solmari, Lelabori, Borigaon, HabiBarangabari, Hatibat, Simaluguri, PatKumoi, Gacharguri, Manipur, Basarbori, Dighalbori, Guchurabori, Pachatia, Morigaon, Bakarigaon, Basanaghat, Garmari, Titatola, Loabhurunga, Kushtoli, Garapara, Gerua, Borchala, Charaihagi, Akorabori, BhurbandhaOuguri, Jalugutimachkhuwa, Ajarbari, Baghara, Mikirbheta, Ghumatigaon, Alikuchi, Uabori, Choratbari, Charaibahi, Dalangghat etc. The GosaiUliuwaMela festival has turned to a common festival of all the Assamese Hindus of the region. Now in the age of democracy and in the time of globalization, the role of those families of the Kings of the Koch and the Tiwas are limited to the observance of such type of festivals and cultural programmes. 


\section{Mela festivals of the Tiwas of Middle Assam and Prospects of Tourism}

Tourism sector in the State of Assam is now developing as a source of income and employment generation. But all the aspects and fields are not yet covered by the authorities for development in this regard. It requires the desire of the communities to share the legacies with tourists, an accessible travel market during the festivals.

Some measures for effective development of tourism in the Mela Festivals of Tiwas as follows.

1. Well-planned Publicity - Intensive campaign should be carried out by government and private agencies. The satellite TV and radio channels can be used for publication at national and international level.

2. Improved infrastructure - Both the government and private tourism agencies should try to promote infrastructure facilities for tourists to enjoy their stay in minimum cost in the areas of attraction.

3. Promotional venture of potential tourism products of the Tiwas like indigenous craft, folk art, performing art, costumes, music and cultural components used in the Melas and religious performs.

4. It should be made aware the local people of the value of the cultural heritage in tourism development through education and special awareness programmes.

5. All festival sites should have the provisions to display the history and significance to facilitate tourists and guests.

6. Involvement of self help groups and local societies get scope to improve their market in these Melas. It helps in the exposure of the local crafts and products. Government special aid is necessary to raise these products. The Tiwa Autonomous Council should give special attention in this regard.

\section{Conclusion}

By promoting attraction of the tourists to the Mela festivals, it could be raised to an important income and employment generating sector if well planned by the Govt and non-govt organizations. Increase of cultural awareness and activityproduce a wide range of social benefits too. The JunbeelMela as a symbol of ancient barter system is an accessible travel market. The present tradition of GosainUliuwaMela represents the assimilation of Tiwa and Neo-Vaishnavite culture in Middle Assam. 


\section{References :}

Barua, Anil Kumar:

Das, Bhuban M:

Deury, Maneswar:

Gogoi, Lokeswar,:

Medhi, B.K., Athparia R.P.

\&Sud, J.K. (ed):

Nath, Jibakanta (ed):

Sen, Soumen :
1989, TheLalungs (Tiwas), Tribal Research Institute, Guwahati

1966, A common perspective for North East India.(Edited By :RathinMittra\&BarunDasgupta)

1994, MorigaonJilarLokaSanskriti, AsomSahitya Sabha, Morigaon.

1986, TiwaSanskritirRuprekha (PrathamKhanda), AsomSahitya Sabha.

2009, Tribes of North East India : Issues and Challenges, Omsons

Publications, New Delhi.

1999, Morigaon, SindhurMajatBindu, Morigaon.

1985, Folkore in North East India, Omsons Publications, New Delhi. 